\title{
Decreased testosterone levels after caponization leads to abdominal fat deposition in chickens
}

\author{
Xiaoyan Cui ${ }^{1,2,3 \dagger}$, Huanxian Cui ${ }^{1,2 \dagger}$, Lu Liu ${ }^{1,2+}$, Guiping Zhao ${ }^{1,2}$, Ranran Liu ${ }^{1,2}$, Qinghe Li ${ }^{1,2}$, Maiqing Zheng ${ }^{1,2}$
} and Jie Wen ${ }^{1,2^{*}}$ (D)

\begin{abstract}
Background: Caponization results in reduced androgen levels, which leads to abdominal fat accumulation in capons. In this study, we sought to understand the molecular mechanisms behind this fat accumulation.

Results: Abdominal fat (AF) content increased significantly $(P<0.05)$ and serum and AF testosterone levels decreased significantly $(P<0.05$ or $P<0.01)$ after caponization. In AF tissue, 90 differentially expressed genes related to lipid metabolism were screened by gene expression profiling in caponized and sham-treated chickens. Among these, six representative genes were significantly up-regulated (APOA1, SCD, FABP7, RXRG, and FADS2) or down-regulated (FABP3) $(P<0.05$ or $P<0.01)$ and were strongly associated with the PPAR pathway. In addition, cell junction pathways were also enriched. In vitro, Fat content was significantly lower in cells treated with testosterone compared with control cells $(P<0.01)$, and mRNA levels of RXRG, FABP7, and FABP3 changed accordingly, confirming the effect of testosterone on fat deposition.

Conclusions: The results of this study indicate that testosterone reduction likely regulates gene expression through PPAR and cell junction pathways resulting in increased fat accumulation. These results provide increase our understanding of the biological mechanisms by which caponization induces greater fat accumulation.
\end{abstract}

Keywords: Capon, Testosterone, Lipid metabolism, Differential expression gene, PPAR pathway

\section{Background}

Capons are castrated male chickens using a technique called caponization. Caponized chicken meat is more tender, juicy, and flavorful than that of intact cockerels and is; therefore, produced for specialized market [1-3]. Capon meat is more tender that of cockerels because caponization results in greater increases in subcutaneous, intercellular, and abdominal fat compared with fat accumulation in intact cockerels $[4,5]$, which improves meat flavor.

Caponization has been shown to cause a significant reduction in testosterone levels in roosters. In male mammals, androgen levels play an important role in

\footnotetext{
* Correspondence: wenjie@caas.cn

'Equal contributors

${ }^{1}$ Institute of Animal Sciences, Chinese Academy of Agricultural Science, Beijing 100193, China

${ }^{2}$ State Key Laboratory of Animal Nutrition, Beijing 100193, China

Full list of author information is available at the end of the article
}

adipogenesis [6-10]. Until now, the molecular mechanisms of how androgen levels affect lipogenesis in the avian species were not known. Using the Beijing-You (BJY) chicken, a typical local breed in China, an investigation on global gene expression profiles related to lipid metabolism in abdominal fat following caponization was performed using gene expression profiling. Our data clarify the regulatory mechanisms that influence fat accumulation in caponized chickens and provides interesting insights into these processes.

\section{Methods \\ Animal and experimental design}

This study was conducted in accordance with the Guidelines for Experimental Animals established by the Ministry of Science and Technology (Beijing, China). All experimental protocols were approved by the Science Research Department (in charge of animal welfare

(c) The Author(s). 2018 Open Access This article is distributed under the terms of the Creative Commons Attribution 4.0 International License (http://creativecommons.org/licenses/by/4.0/), which permits unrestricted use, distribution, and 
issues) of the Institute of Animal Sciences, Chinese Academy of Agricultural Sciences (Beijing, China). The BJY hatchlings came from conservation stock (Institute of Animal Science, Chinese Academy of Agricultural Sciences, Beijing, China), and all chickens had the same genetic background. The birds were raised in an environmentally controlled room in three-story step cages. Basal diets were formulated based on the National Resource Council (1994) requirements and the Feeding Standards of Chickens established by the Ministry of Agriculture, Beijing, China (2004). Feed and water were provided ad libitum.

Sixty 3-week-old male chicks with similar body weights were randomly divided into two groups (30 individuals per group). Chicks in one group were caponized while the others underwent a sham operation as the control group. The caponization procedure was performed in accordance with previously described methods $[4,11]$. All the capons and control chicks were housed together under standard poultry housing conditions.

Ten birds from each of the two groups were euthanized under carbon dioxide anesthesia by severing the carotid artery at 10,14, and $19 \mathrm{w}$ after caponization or sham operations. Experienced technicians performed the euthanasias. After a 12-h overnight fast with free access to water, and before euthanasias, blood samples were taken from the brachial veins of chickens. Serum was separated and frozen at $-80{ }^{\circ} \mathrm{C}$ until sex hormone concentrations were determined. After slaughter, AF was dissected in the same area for all chickens. The AF samples were weighed, snapfrozen in liquid nitrogen, and stored at $-80{ }^{\circ} \mathrm{C}$ until use. The remaining AF tissues were removed and weighed, which included the AF pad and fat around the gizzard. The abdominal fat weight (AFW) was recorded, and the AF percentage (AFP, \%) was calculated (mass of AF as a percentage of live weight).

\section{Determination of serum and AF testosterone levels}

Serum testosterone and estradiol concentrations were determined using a radioimmunoassay kit (Huaying, Beijing, China) as previously described method [12]. Testosterone levels in AF were also measured using a chicken-specific testosterone ELISA kit (Fangcheng Biological Technology Co., Ltd., Beijing, China). Samples were homogenized at room temperature and centrifuged $(1000 \times g, 20 \mathrm{~min})$ at $4{ }^{\circ} \mathrm{C}$ to separate the fat from other debris, and the resultant infranatant fluid was frozen immediately at $-80{ }^{\circ} \mathrm{C}$ until use. The assay was performed according to the manufacturers instructions after dilution to optimize accuracy.

\section{RNA extraction}

Total RNA was isolated from AF tissues (each sample was about $100-150 \mathrm{mg}$ ) and fat cells using a commercially available kit according to the manufacturer's instructions (Tiangen, Beijing, China). The concentration and purity of RNA were determined by $A_{260}$ and $A_{260: 280}\left(A_{260: 280} \geq 1.8\right.$ and $\leq 2.0$ ) using a NanoDrop ND-1000 spectrophotometer (Nanodrop Technologies, Wilmington, DE, USA). RNA integrity $(\mathrm{RIN} \geq 7)$ was assessed by electrophoresis on a $1 \%$ agarose gel and the Agilent 2100 Bioanalyzer (Agilent Technologies, Palo Alto, CA, USA). RNA samples were stored at $-80^{\circ} \mathrm{C}$ until they were used.

\section{Gene expression profiling}

Based on ultra-high-throughput sequencing (HiSeq 2500; Illumina, San Diego, CA, USA), gene expression profiling was undertaken by Berry Genomics (Beijing, China) using total RNA from AF samples in three each of capon and control chickens (taken $14 \mathrm{w}$ after caponizations or sham operations). RNA with good integrity was used to construct the library, and the six cDNA libraries were prepared according to Illumina's instructions and then, sequenced. Raw data were converted to FASTQ files using bcl2fastq. "Clean" data were obtained by filtering and removing low-quality sequences and mapped to the reference chicken genome and genes (Gallus_gallus, Galgal4; available at https://www.ncbi. nlm.nih.gov/assembly/GCF_000002315.3) using TopHat 1.3.2. Gene expression levels were calculated using the RPKM (Reads Per Kb per Million mapped reads) method as described by Mortazavi et al. [13]. Differentially expressed genes (DEGs) between the treatment and control groups were analyzed using the edge $R$ package. To screen for DEGs, we used the following criteria: fold change $\geq 1.5$ or $\leq 0.67$, with $P<0.05$.

Gene Ontology (GO) enrichment analysis was performed for features corresponding to DEGs using the DAVID software toolkit. The significance level for GO term enrichment was set with a False Discovery Rate (FDR) adjusted and a $p$-value $<0.05$, by the Benjamini and Yekutieli method [14]. The Kyoto Encyclopedia of Genes and Genomes (KEGG) pathway enrichment analysis was performed using the KOBAS 2.0 (kobas.cbi. pku.edu.cn/help.do) $[15,16]$. Pathways significantly associated with DEGs were identified using a hypergeometric test from the $\mathrm{R}$ packages $(P<0.05$, FDR-adjusted). Pathways with fewer than three known chicken genes were discarded.

\section{Primary preadipocyte acquisition and testosterone treatment}

After the primary preadipocytes were obtained from the AF of chickens (2-4 weeks old; Institute of Animal Science, CAAS) according to a previously reported protocol [17], cells were cultured in DMEM/F12 containing 10\% FBS. At $100 \%$ confluence, cells in three replicate wells of six-well culture dishes were treated with either 0 or 
$30 \mathrm{ng} / \mathrm{mL}$ testosterone. Concurrently, cell differentiation was induced with $10 \mathrm{mg} / \mathrm{mL}$ insulin, $0.5 \mathrm{mmol}$ isobutylmethylxanthine, and $1 \mathrm{mmol}$ dexamethasone for $2 \mathrm{~d}$, followed by a $2 \mathrm{~d}$ treatment with medium containing $10 \% \mathrm{FBS}$ and $10 \mathrm{mg} / \mathrm{mL}$ insulin, and then with medium containing only $10 \%$ FBS. Four days after treatment, cells at a density of $10^{6}$ per milliliter, as measured by a globulimeter, were used for cell differentiation assays, and for determination of $R X R G, F A B P 7$, and FABP3 expression in three replicate wells, respectively. RNA extraction from cells was similar to that performed for the AF. Total RNA was also prepared and stored for the quantitative polymerase chain reaction (qPCR) assays.

\section{The cell differentiation assay}

For Oil Red-O staining, cells were fixed in $4 \%$ paraformaldehyde for $30 \mathrm{~min}$ and washed twice with PBS. They were then immersed in a $0.3 \%$ Oil Red-O solution for $2 \mathrm{~h}$. After removing the background Oil Red-O staining with three PBS washes, the stained triglyceride droplets were visualized and photographed. The Oil Red-O staining was then eluted with $100 \%$ isopropanol in each well. The eluant absorbance was quantified using a microplate reader at $510 \mathrm{~nm}$. For each group, three replicate wells were used for experimental accuracy. Preadipocyte cultures and differentiation assays were also performed in triplicate.

\section{Real-time quantitative PCR (qRT-PCR)}

Using the same RNA samples as used for gene expression profiling, qRT-PCR was performed to confirm the results of gene expression profiling, and 11 representative genes related to lipid metabolism were selected. In addition, in cells treated with 0 or $30 \mathrm{ng} / \mathrm{mL}$ testosterone, the RXRG, FABP7, and FABP3 expression levels were also detected. The RNA samples were reversetranscribed using M-MLV reverse transcriptase (Invitrogen, Carlsbad, CA). The specific primers (Table 1) were designed to yield a single product that was verified by a single melting curve peak and a single band on an agarose gel of the appropriate size. The PCR mixture contained $10 \mu \mathrm{L}$ of $2 \times \mathrm{iQ}^{\mathrm{m}}$ SYBR Green Supermix, $0.5 \mu \mathrm{L}$ (10 mmol) of each primer, and $1 \mu \mathrm{L}$ of cDNA, along with ddH2O making a total volume of $20 \mu \mathrm{L}$. Samples were amplified using the real-time PCR Detection System ABI 7500 (Applied Biosystems, Shanghai, China).

Table 1 Specific qRT-PCR primers used in this study

\begin{tabular}{|c|c|c|c|}
\hline Gene name & Sequence & Product size (bp) & Accession NO. \\
\hline \multirow[t]{2}{*}{$\overline{R X R G}$} & F:5'-AGGCGTGGGCTCCATCTTT-3' & 259 & NM_205294 \\
\hline & R:5'-CCGTAGTGCTGGCAGGC-3' & & \\
\hline \multirow[t]{2}{*}{ FADS2 } & F:5'-CTGAGGAAGACAGCAGAGGACAT-3' & 153 & NM_0011604282 \\
\hline & R:5'-GCAGGCAAGGATTAGAGTTGTG-3' & & \\
\hline \multirow[t]{2}{*}{ FABP7 } & F:5'-CGTGATCAGGACTCAGAGCA-3' & 158 & NM_205308 \\
\hline & R:5'-TCTCTTTGCCATCCCATTTC-3' & & \\
\hline \multirow[t]{2}{*}{$S C D$} & F:5'-GGCTGACAAAGTGGTGATG-3' & 137 & NM_204890 \\
\hline & R:5'-GGATGGCTGGAATGAAGA-3' & & \\
\hline \multirow[t]{2}{*}{ FABP3 } & F:5'-AGTACATGAAGGCGTTGGGG-3' & 171 & NM_001030889 \\
\hline & R:5'-CCGTGGTCTCATCGAACTCC-3' & & \\
\hline \multirow[t]{2}{*}{$A P O A 1$} & F:5'-GTGACCCTCGCTGTGCTCTT-3' & 217 & NM_205525 \\
\hline & R:5'-CACTCAGCGTGTCCAGGTTGT-3' & & \\
\hline \multirow[t]{2}{*}{ MSMO1 } & F:5'-TTCGTACTTCTTGCTCTGCGT-3' & 226 & NM_001006438 \\
\hline & R:5'-CCACCTAGGCATCTCTTCCC-3' & & \\
\hline \multirow[t]{2}{*}{ SQLE } & F:5'-CGCTGACGGTTGTAGCTGAT-3' & 200 & NM_001194927 \\
\hline & R:5'-AAGGACGCGAGTCTCAGTTG-3' & & \\
\hline \multirow[t]{2}{*}{ MGLL } & F:5'-GGAGTCCTCAAAACATCCCATAC-3' & 189 & NM_001277142 \\
\hline & R:5'-CAAACAAGTTAAGTTCTGTCAGCCT-3' & & \\
\hline \multirow[t]{2}{*}{ PTGDS } & F:5'-GACGGACAAGTGTATGGCAG-3' & 118 & NM_204259 \\
\hline & R:5'-CCAGGAAGTAAAGGTGGATATGG-3' & & \\
\hline \multirow[t]{2}{*}{ CYP2D6 } & F:5'-GATTGGAAGAAACCGACCGC-3' & 170 & NM_001195557 \\
\hline & R:5'-TTGTCGTCCCTITGGGAATG-3' & & \\
\hline \multirow[t]{2}{*}{$\beta$-actin } & F:5'-GAGAAATTGTGCGTGACATCA-3' & 152 & NM_205518 \\
\hline & R:5'-CCTGAACCTCTCATTGCCA-3' & & \\
\hline
\end{tabular}


After initial denaturation for $30 \mathrm{~s}$ at $95{ }^{\circ} \mathrm{C}$, amplification was performed for 40 cycles $\left(95^{\circ} \mathrm{C}\right.$ for $5 \mathrm{~s}$ and $60{ }^{\circ} \mathrm{C}$ for $32 \mathrm{~s})$. PCR efficiency for these genes and $\beta$-actin was consistent. To determine fold-changes in gene expression, the comparative CT method was used [18], with fold-change calculated as $2^{-\Delta \Delta C T}$. The results are expressed as the mean fold-change in gene expression from triplicate analyses, using control group samples as the calibrators (arbitrarily assigned an expression level of 1 for each gene). Negative controls, without a cDNA template, were included in this experiment. Correlations between relative abundances from qRT-PCR and gene expression profiling data were also calculated.

\section{Statistical analyses}

Statistical analyses between control and treatment groups were performed using Student's unpaired $t$-test in SPSS Version 16.0 (SPSS Inc., Chicago, IL, USA). Values are reported as the mean \pm standard error of the mean (SEM). Differences were considered statistically significant at $P<0.01$ or $P<0.05$.

\section{Results}

\section{Caponization accelerates AF deposition}

With the passage of time after caponization, increases in both AFW and AFP were gradually accelerated. Compared with the sham-operated control animals, AFW and AFP increases were greater in capons $(P<0.05$ or $P<0.01)$ at 14 and 19 wk. after caponization (Fig. 1a and b). These results suggest that the caponization enhanced AF deposition. And, 14 wk. after caponization, serum and AF samples were used for subsequent experimentation.

\section{Differential AF gene expression 14 weeks after caponization}

To understand the changes in AF deposition in capons compared with controls, AF samples were obtained $14 \mathrm{w}$ after caponization to screen for potential candidate genes that affect $\mathrm{AF}$ accumulation. Using gene expression profiling, a total of 872 DEGs $(\log 2>0.58$ or $<-0$. 58 , with $P<0.05$ ) between capons and control group chickens were screened: 463 were up-regulated and 409 were down-regulated in capons compared with controls (Additional File 1).

Based on known DEGs, a cluster analysis of all six samples was performed to validate data from the gene expression profiling using Cluster 3.0 software, and it revealed that three samples each from the same group were clustered together (Fig. 2). To validate the data obtained from gene expression profiling, 11 representative DEGs were selected to examine the relative expression using qRT-PCR. As shown in Fig. 3, the fold changes of expression of these genes by gene expression profiling and qRT-PCR were highly correlated $(r=0.9461, P<0.01)$.

GO analysis was performed based on known DEGs and identified particular GO terms in the main biological processes category, included the following processes: lipid metabolism, regulation of cell differentiation, cell cycle, protein metabolism, hormone metabolism, transmembrane transport, oxidation-reduction, muscle system, regulation of the immune system, blood circulation, regulation of apoptosis, and ATP biosynthesis (Additional File 2). Moreover, GO enrichment analysis indicated that the largest proportion of DEGs was involved in metabolic pathways, and 90 genes were associated with lipid metabolism, including 42 up-regulated and 48 down-regulated genes (Additional File 3).
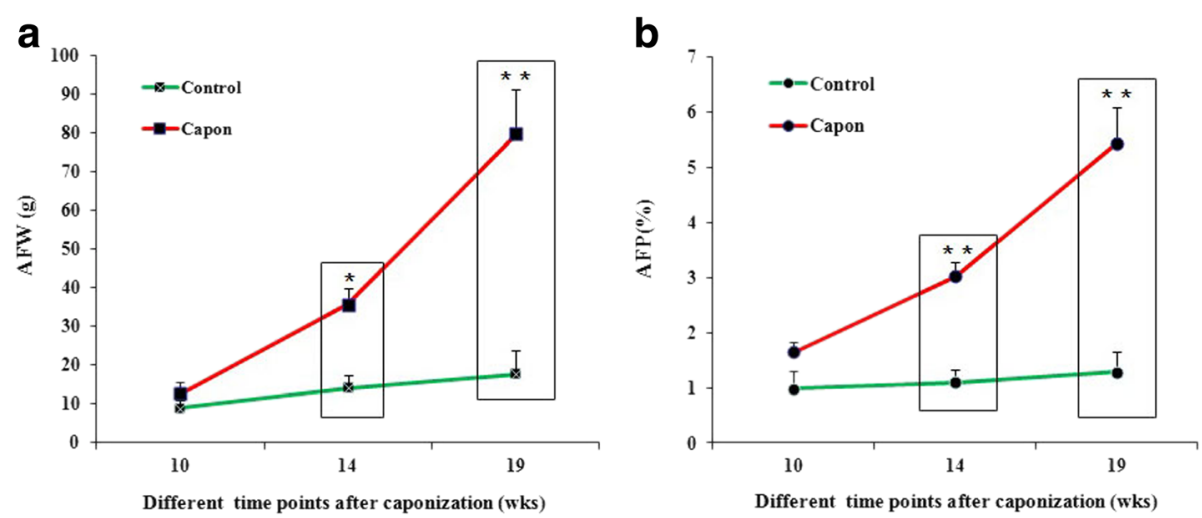

Fig. 1 AFW and AFP increase in the abdominal fat of male chickens after caponization. a Caponization accelerates AFW in male chickens. The AFWs of Chickens after caponization (capons) or not (sham-operated chickens), were recorded at 10, 14, 19 wks, respectively. The results show that AFW significantly increases in capons compared with control chickens at 14 wk. and 19 wk. after caponization. b Caponization improves AFPs in male chickens. AFP (\%) is expressed as a percentage of AFW/live weight and significantly increased in capons compared with sham-operated control chickens at 14 wk. and 19 wk. after caponization. Data are presented as means \pm SEM, $n=10$. ${ }^{*} P<0.05 ;{ }^{* *} P<0.01$ 


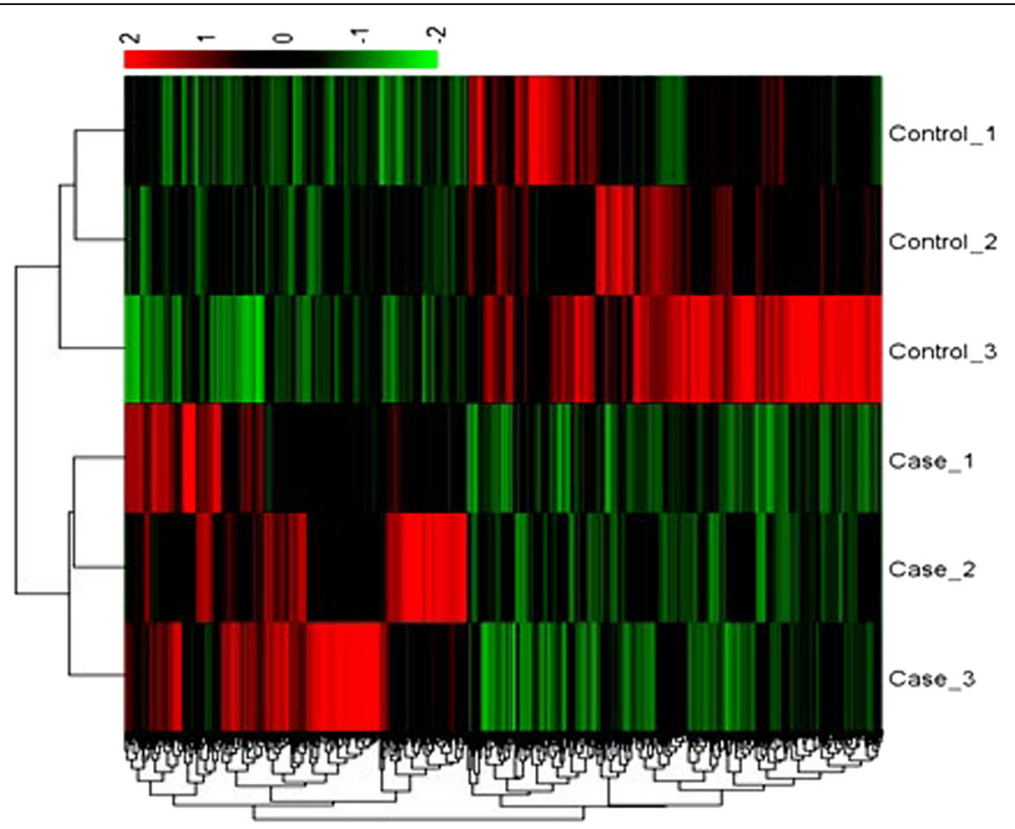

Fig. 2 Cluster analysis of AF tissue of capons vs. sham-operated control chickens . a Cluster analysis heat-map data using the gene expression profiling. Using Cluster 3.0 software and based on the 872 known DEGs in the AF tissue of capons vs. sham-operated control chickens 14 wk. after caponization, heat-maps of all six samples demonstrated that the three samples in each the capon and the control groups were clustered together, respectively

\section{AF gene expression is enriched for pathways involved in} lipid metabolism after caponization

Based on the known DEGs, KEGG analysis was performed, and the 9 significantly enriched $(P \leq 0.05)$ pathways were screened (Additional File 4, Fig. 4a), including well-known pathways related to lipid metabolism (PPAR signaling, arachidonic acid metabolism, and fatty acid

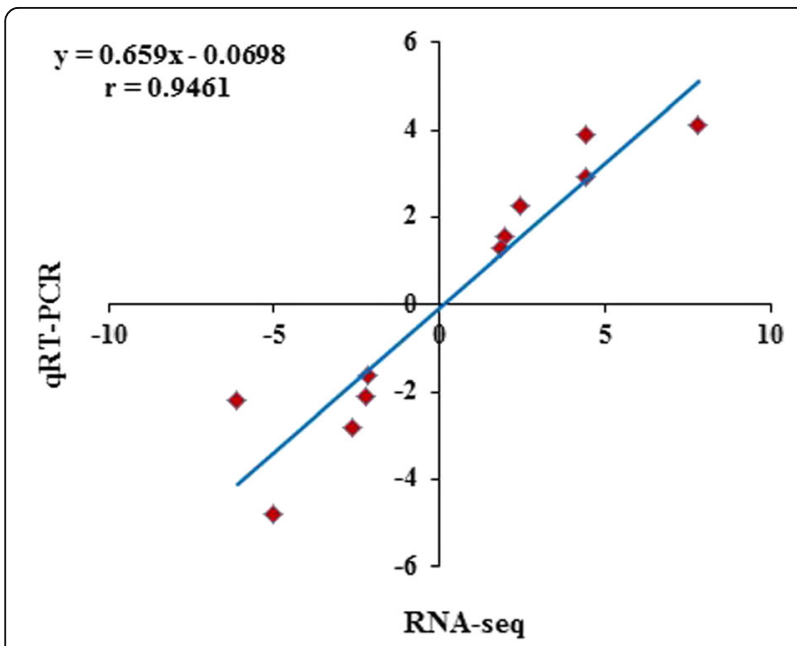

Fig. 3 Data verification from Gene Expression Profiling analysis by Q-PCR. $\mathbf{b}$ The correlation analysis examined the fold-changes of 11 DEGs measured by gene expression profiling and Q-PCR to validate the gene expression profiling results. The data were highly correlated $(r=0.9461, P<0.01)$, indicating that the results from the gene expression profiling were accurate $(n=11)$ metabolism) and cell junctions (ECM-receptor interaction, cell adhesion molecules (CAMs), cytokinecytokine receptor interaction, and focal adhesion).

As for the PPAR pathway, 11 genes related to lipid metabolism, including 6 representative genes (apolipoprotein A1, APOA1; fatty acid-binding 3, FABP3; fatty acid-binding 7, FABP7; retinoid $\mathrm{X}$ receptor-gamma, RXRG; stearoyl-CoA desaturase, SCD; fatty acid desaturase 2, FADS2), were specifically associated with the PPAR signaling pathway (Additional File 5: Figure S1), and the mRNA levels of these genes changed significantly $(P<0.05$ or $P<0.01)$ in the capons compared with controls (Fig. 4b), suggesting that caponization induces gene expression changes that regulate AF deposition.

\section{Decreased testosterone levels influence AF deposition after Caponization}

Given that the role of sex hormones in lipid metabolism was previously reported [4], the relationship between testosterone and estradiol and AF deposition was also explored here. First, the serum levels of testosterone and estradiol were determined. As shown in Fig. 5a, serum testosterone levels significantly decreased $(P<0.01) 14$ wk. after caponization in the capon group compared with those of the control group. In contrast, serum estradiol levels did not differ $(P>0.05)$ between the two groups 14 wk. after caponization or sham operations (Fig. 5b). 


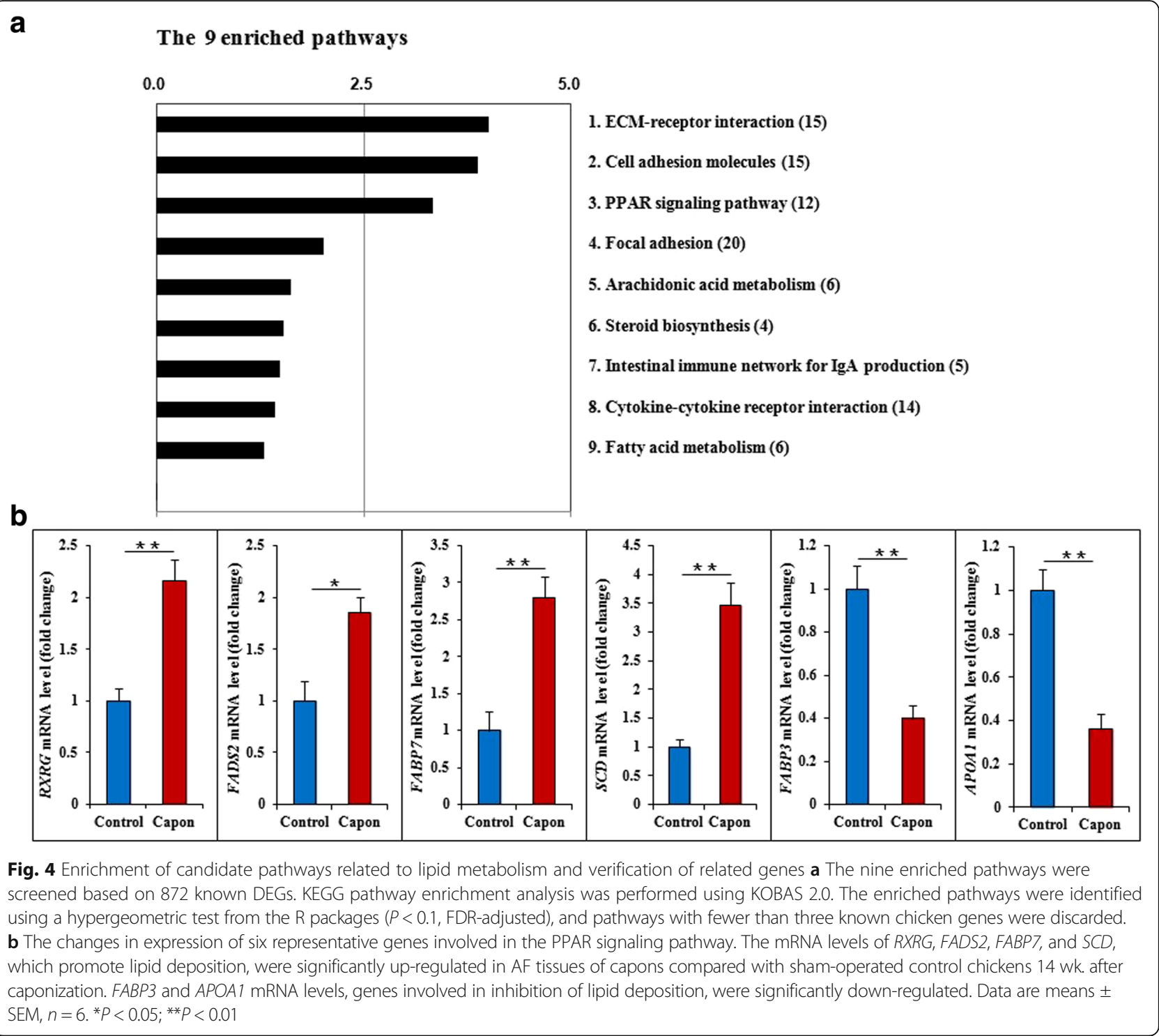
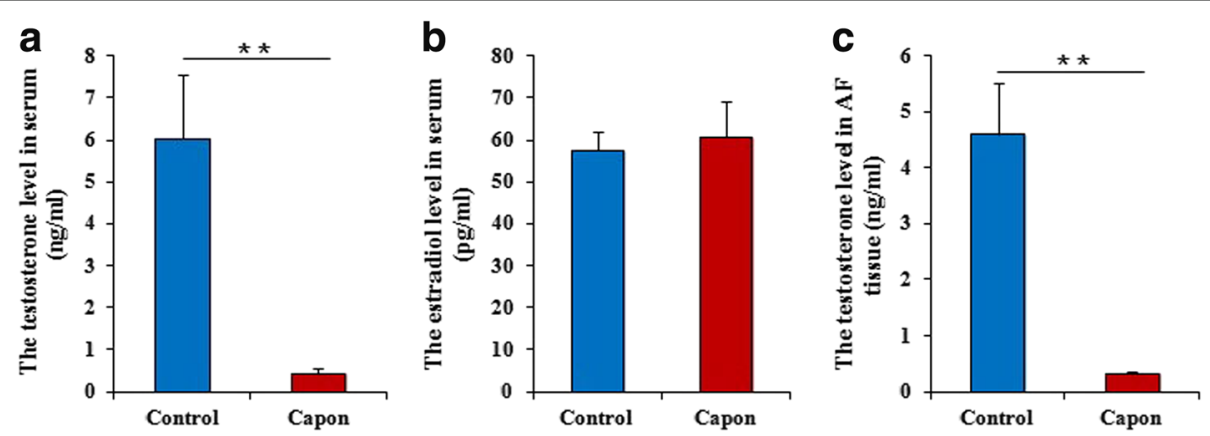

Fig. 5 Sex hormone levels in capons vs. control chickens. a and (c) Serum and AF testosterone levels were significantly reduced in capons compared with sham-operated control chickens. 14 wk. after caponization, testosterone levels were measured with an ELISA kit. b Serum estradiol levels were not different between the capons and the control chickens. 14 wk. after caponization, serum estradiol levels were detected with an ELISA kit. Data are means $\pm \mathrm{SEM}, \mathrm{n}=10$. ${ }^{*} P<0.05 ;{ }^{* *} P<0.01$ 
Fourteen wks after caponization, chicken AF testosterone levels were determined using an ELISA. As shown in Fig. 5c, the results showed that capon AF had lower testosterone levels $(P<0.05)$ compared with control AF, suggesting that the reduction in serum and AF testosterone levels might correlate with greater AF deposition.

An additional in vitro experiment (with 0 or $30 \mathrm{ng} / \mathrm{mL}$ testosterone) was performed to confirm the effect of testosterone on AF deposition. Preadipocyte cell differentiation was detected by Oil Red-O staining after cells were cultured and treated with testosterone or not for $4 \mathrm{~d}$. The fat content in cells treated with testosterone was significantly lower $(P<0.01)$ than in untreated cells (Fig. 6a). Similarly, the expressions of RXRG, FABP3, and FABP7 (the important factor involved in the PPAR signaling pathway) were also detected, which showed that $R X R G$ and FABP7 mRNA levels were significantly downregulated $(P<0.01, P<0.01)$, and $F A B P 3$ mRNA levels were significantly up-regulated $(P<0.01)$ in cells treated with testosterone for $4 \mathrm{~d}$ compared with untreated cells (Fig. 6b).

\section{Discussion}

Testosterone, an important androgen, is a major determinant of body composition in male mammals $[8,19]$. It has been reported that caponization accelerates AF deposition in male chickens, which is accompanied by decreased testosterone levels $[4,5]$. Similarly, abdominal obesity in men is usually associated with a low serum

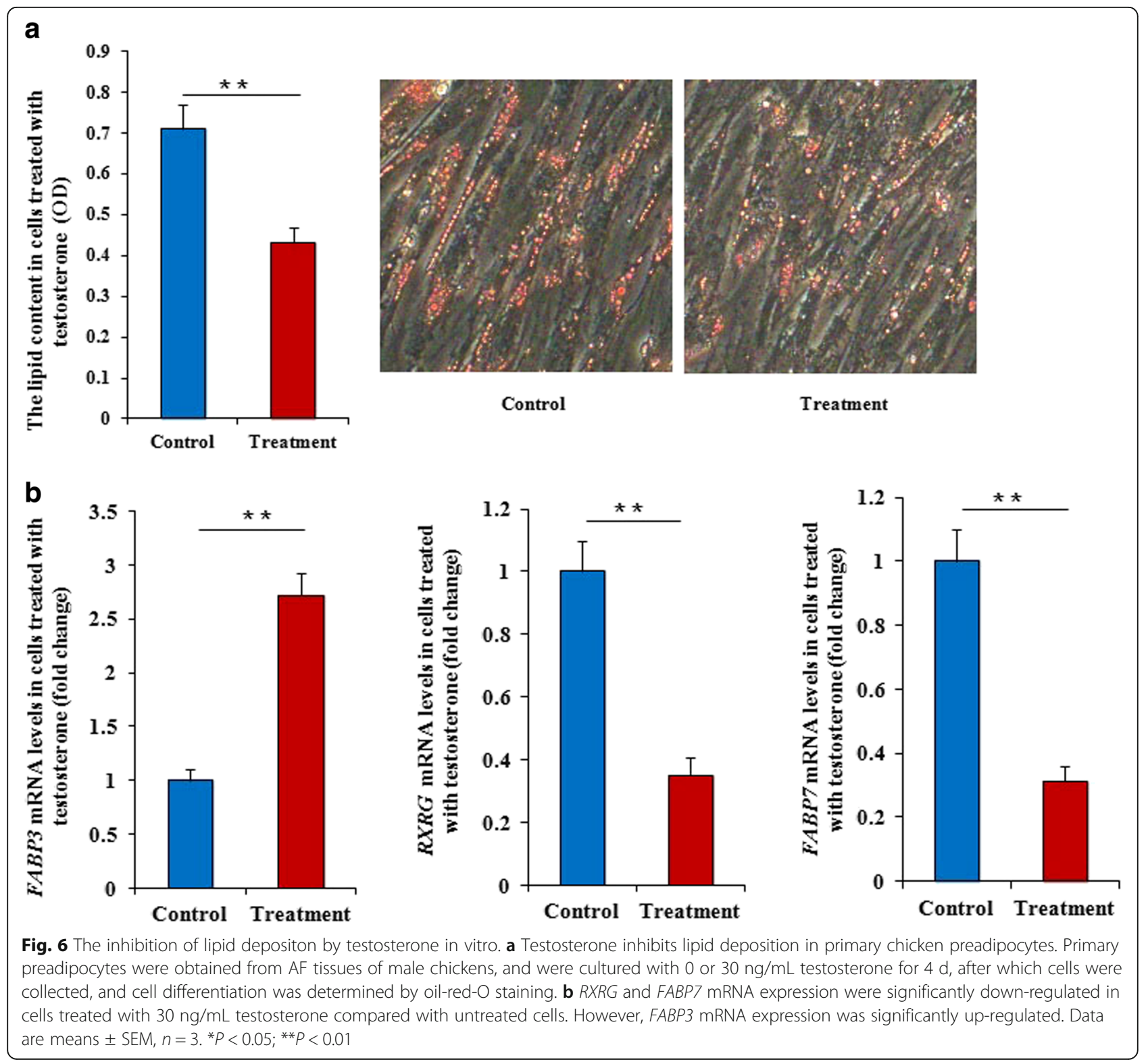


testosterone level $[8,20]$. Therefore, it was speculated that caponization would induce fat accumulation by reducing testosterone levels in male chickens, although the molecular mechanisms behind this hypothesis have remained incompletely understood. It is known that intramuscular fat (IMF)has high genetic correlations with AFW and moderate correlations with AFP in chickens [21]. As AF changes, it can change IMF [22-24], which plays an important role in meat quality. Considering the importance of caponization to chicken meat quality, this study was thus intended to reveal the molecular mechanisms behind fat accumulation associated with caponization in chickens.

Using capons, the findings of this study showed that serum testosterone levels were significantly reduced with greater AF accumulation in caponized chickens compared with controls, which is consistent with previous observations [4, 25]. Testosterone, as a circulating blood hormone, can reach distant target tissues to exert its biological functions $[7,10]$. The findings indicate that reduced serum and AF testosterone levels might be related to AF deposition after caponization in male chickens. Further, the addition of testosterone to preadipocytes significantly decreased cellular fat deposition. Remarkably, both in vitro and in vivo studies reached the same conclusions, which show that caponization accelerates AF deposition because of reduced testosterone levels.

Based on the results of AF deposition and reduced serum testosterone levels after caponization, the $\mathrm{AF}$ tissue samples from capons and sham-operated controls were subjected to gene expression profiling to screen for DEGs and the enriched pathways after caponization in capons versus control chickens. The results of cluster analysis and qRT-PCR supported the accuracy of the gene expression profiling.

GO and KEGG analyses based on 872 known DEGs were performed, and 90 DEGs related to lipid metabolism were further screened, including $R X R G, F A B P 3$, and FABP7 [26-29]. Among the nine enriched pathways, classical pathways related to lipid metabolism (PPAR and fatty acid metabolism) were screened, and six representative DEGs related to lipid metabolism (APOA1, SCD, FABP3, FABP7, RXRG, and FADS2) were enriched and identified in the PPAR pathway. Considering the importance of the PPAR pathway and the genes related to lipid metabolism [30-35], it was shown that caponization-accelerated AF deposition might be associated with the changed expression of related genes through the PPAR pathway in the AF of chicken. Guo et al. found that caponization increased abdominal fat percentages in Guang-xi Yellow roosters and that FAS, $L P L$, and PPARY mRNA expression levels of FAS, LPL and PPARY genes, which are associated with the PPAR signaling pathway, were significantly up-regulated [36]. For the DEGs, the reasons for these discrepancies could be attributed to breed differences and age at the time of slaughter. In addition, pathways related to cell junctions (ECM-receptor interactions, CAMs, cytokine-cytokine

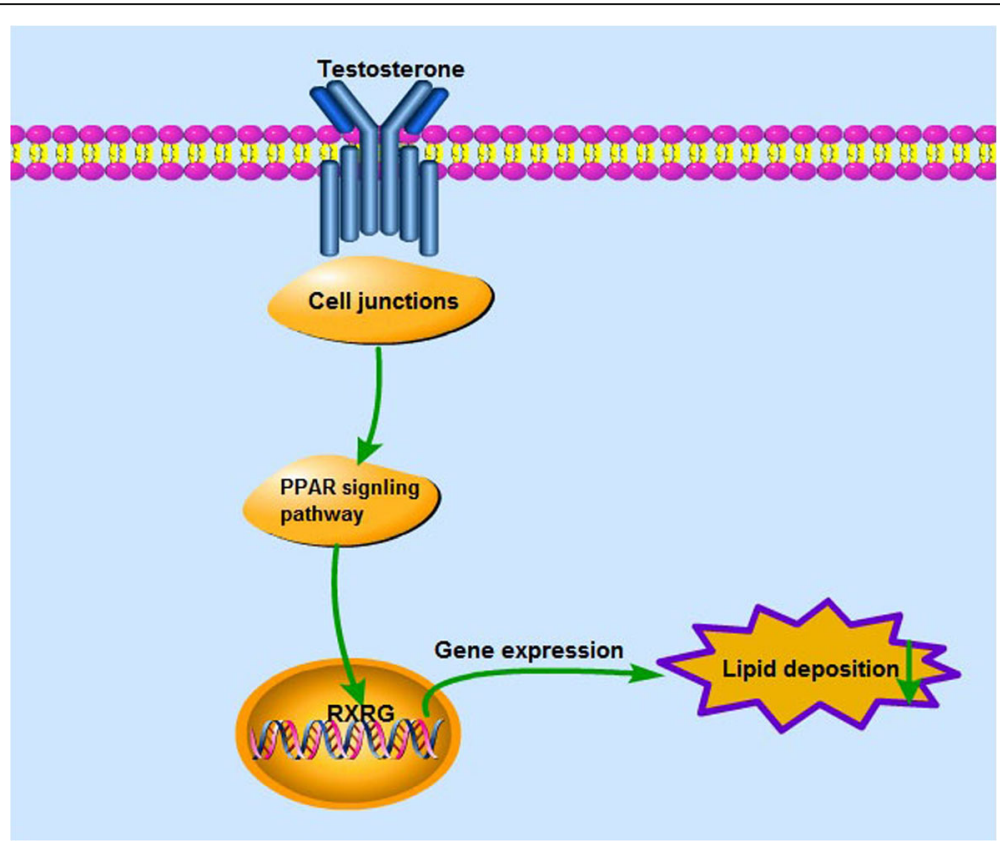

Fig. 7 The regulatory network regarding the influence of reduced testosterone levels on lipid deposition in caponized chickens, which is based on significantly enriched KEGG pathwaysThis network is involved in the cellular functions of lipid metabolism (PPAR signaling pathway) and cell junctions. 
receptor interactions, and focal adhesions) were enriched in this study, which showed that these pathways promoted activation of the PPAR pathway to induce AF deposition in chickens, consistent to what was shown in the study by Cui et al. [37]. In the present study, these findings support the assertion that pathways related to cell junctions are also involved in testosterone the regulation of AF deposition.

An additional in vitro experiment (with 0 or $30 \mathrm{ng} / \mathrm{mL}$ testosterone) was performed in this study to confirm the effect of testosterone on fat deposition. Cell differentiation was detected by Oil Red-O staining after cells had been treated for $4 \mathrm{~d}$, and the fat content in treated cells was significantly lower $(P<0.01)$ than in untreated ones. Similarly, the expressions of RXRG, FABP3 and FABP7 (the important factor involved in the PPAR signaling pathway) was also detected. The results showed that RXRG and FABP7 mRNA levels were significantly down-regulated $(P$ $<0.01, P<0.01)$, and FABP3 mRNA level were significantly up-regulated $(P<0.01)$ in cells treated with testosterone for $4 \mathrm{~d}$ compared with those in untreated cells. Together, these analyses demonstrate that pathways related to cell junctions (focal adhesion, ECM-receptor interaction, cytokine-cytokine receptor interaction, and CAMs), and PPAR might form networks with pathways related to lipid metabolism to influence the AF deposition in male chickens after caponization (Fig. 7).

\section{Conclusions}

In conclusion, our study hypothesized that reduced testosterone levels after caponization accelerates AF deposition by changing the expression of related genes through cell junctions and PPAR pathways in the AF of male chickens. These findings provide a useful foundation for deciphering the molecular mechanisms underlying AF deposition in capons. Additional studies of the associated translational and post-translational effects are required to complement these mRNA expression analyses.

\section{Additional files}

Additional file 1: 872 DEGs between the capon and the control chicken groups. (XLS $311 \mathrm{~kb}$ )

Additional file 2: The enriched the GO-terms in the BP category based on 872 DEGs. (XLS $50 \mathrm{~kb}$ )

Additional file 3: The 86 DEGs related to lipid metabolism using GOterms analysis based on a total of 872 DEGs 45 up-regulated and 41 down-regulated. (XLS $75 \mathrm{~kb}$ )

Additional file 4: The enriched pathways based on the 872 DEGs. (XLS $61 \mathrm{~kb})$

Additional file 5: Figure S1. The PPAR signaling pathway (JPG $109 \mathrm{~kb})$

\section{Abbreviations}

AF: Abdominal fat; AFP: Percentage of AFW; AFW: Abdominal fat weight; APOA1: Apolipoprotein A1; BJY: Beijing-You; CAMs: Cell adhesion molecules; CT: Cycle threshold; CYP2D6: Cytochrome P450 2D6; DEG: Differentially expressed gene; FABP: Fatty acid binding protein; FADS2: Fatty acid desaturase 2; FBS: Fetal bovine serum; GO: Gene Ontology; IMF: Intramuscular fat; KEGG: Kyoto Encyclopedia of Genes and Genomes; MGLL: Monoacylglycerol lipase; MSMO1: Methylsterol monooxygenase 1; PPAR: Peroxisome proliferator-activated receptor; PTGDS: Prostaglandin D synthase; qRT-PCR: Real-time quantitative polymerase chain reaction; RXRG: Retinoid X receptor-gamma; SCD: Stearoyl-CoA desaturase; SQLE: Squalene monooxygenase

\section{Acknowledgments}

The authors would like to acknowledge Joel Anderson and EditorBar for providing the English edits on this manuscript.

\section{Funding}

The study was supported by grants from the National Natural Science Funds of China (No. 31372305) (for the design of the study, and the collection, analysis, interpretation of data of capons and the gene expression profile), the Earmarked Fund for Modern Agro-Industry Technology Research System (CARS-41)(for the analysis and interpretation of data of the gene expression profile), and the Agricultural Science and Technology Innovation Program (ASTIP-IAS04, ASTIP-IAS18, ASTIP-IAS-TS-11) (for the analysis, interpretation of data of the cell experiment in vitro and writing the manuscript).

\section{Availability of data and materials}

The data sets supporting the conclusions of this article are included in the article and its additional files.

\section{Authors' contributions}

JW and GZ contributed to the design of the study. XC, HC and LL performed the study design, data interpretation, and the manuscript writing. RL, QL and $\mathrm{MZ}$ contributed to data interpretation and manuscript writing. All authors submitted comments on drafts, and read and approved the final manuscript.

\section{Ethics approval and consent to participate}

This study was conducted in accordance with the Guidelines for Experimental Animals established by the Ministry of Science and Technology (Beijing, China). The protocol was approved by the Science Research Department (in charge of animal welfare issues) of the Institute of Animal Sciences, Chinese Academy of Agricultural Sciences (Beijing, China). Consent to participate: Not applicable.

Competing interests

The authors declare that they have no competing interests.

\section{Publisher's Note}

Springer Nature remains neutral with regard to jurisdictional claims in published maps and institutional affiliations.

\section{Author details}

${ }^{1}$ Institute of Animal Sciences, Chinese Academy of Agricultural Science, Beijing 100193, China. ${ }^{2}$ State Key Laboratory of Animal Nutrition, Beijing 100193, China. ${ }^{3}$ Institute of Animal Science, Guangdong Academy of Agricultural Sciences, Guangzhou 510640, China.

Received: 22 October 2017 Accepted: 26 April 2018

Published online: 09 May 2018

\section{References}

1. Rikimaru K, Ogawa S, Komastu M, Ishizuka J. Effects of caponization on meat quality of Hinai-jidori chicken. J Poult Sci. 2009;46:345-50

2. Sirri F, Bianchi M, Petracci M, Meluzzi A. Influence of partial and complete caponization on chicken meat quality. Poult Sci. 2009;88:1466-73.

3. Symeon GK, Mantis F, Bizelis I, Kominakis A, Rogdakis E. Effects of caponization on growth performance, carcass composition, and meat quality of medium growth broilers. Poult Sci. 2010;89:1481-9.

4. Duan J, Shao F, Shao Y, Li J, Ling Y, Teng K, Li H, Wu C. Androgen inhibits abdominal fat accumulation and negatively regulates the PCK1 gene in male chickens. PLoS On. 2013;8:e59636.

5. Symeon GK, Mantis F, Bizelis I, Kominakis A, Rogdakis E. Effects of caponization on growth performance, carcass composition and meat quality of males of a layer line. Animal. 2012;6:2023-30. 
6. Singh R, Artaza JN, Taylor WE, Gonzalez-Cadavid NF, Bhasin S. Androgens stimulate myogenic differentiation and inhibit adipogenesis in C3H 10T1/2 pluripotent cells through an androgen receptor-mediated pathway. Endocrinology. 2003;144:5081-8.

7. Pasquali R. Obesity and androgens: facts and perspectives. Fertil Steril. 2006; 85:1319-40.

8. Blouin K, Nadeau M, Perreault M, Veilleux A, Drolet R, Marceau P, Mailloux J, LuU-The $V$, Tchernof A. Effects of androgens on adipocyte differentiation and adipose tissue explant metabolism in men and women. Clin Endocrino. 2010;72:176-88.

9. Chazenbalk G, Singh P, Irge D, Shah A, Abbott DH, Dumesic DA. Androgens inhibit adipogenesis during human adipose stem cell commitment to preadipocyte formation. Steroids. 2013;78:920-6.

10. Singh R, Artaza JN, Taylor WE, Braga M, Yuan X, Gonzalez-Cadavid NF, Bhasin S. Testosterone inhibits adipogenic differentiation in 3T3-L1 cells: nuclear translocation of androgen receptor complex with $\beta$-catenin and Tcell factor 4 may bypass canonical Wnt signaling to down-regulate adipogenic transcription factors. Endocrinology. 2006;147:141-54.

11. Chen K, Chi W, Chiou P. Caponization and testosterone implantation effects on blood lipid and lipoprotein profile in male chickens. Poult Sci. 2005;84:547-52.

12. Dorgan JF, Fears TR, McMahon RP, Friedman LA, Patterson BH, Greenhut SF. Measurement of steroid sex hormones in serum: a comparison of radioimmunoassay and mass spectrometry. Steroids. 2002;67:151-8.

13. Mortazavi A, Williams BA, Mc Cue K, Schaeffer L, Wold B. Mapping and quantifying mammalian transcriptomes by RNA-Seq. Nat Methods. 2008:5:621-8.

14. Benjamini $Y$, Yekutieli $D$. The control of the false discovery rate in multiple testing under dependency. Ann Stat. 2001;29:1165-88.

15. Mao X, Cai T, Olyarchuk JG, Wei L. Automated genome annotation and pathway identification using the KEGG Orthology (KO) as a controlled vocabulary. Bioinformatics. 2005;21:3787-93.

16. Wu J, Mao X, Cai T, Luo J, Wei L. KOBAS server: a web-based platform for automated annotation and pathway identification. Nucleic Acids Res. 2006; 34:W720-4.

17. Shipp SL, Cline MA, Gilbert ER. Promotion of adipogenesis by neuropeptide $Y$ during the later stages of chicken preadipocytedifferentiation. Physiol. 2016, Rep;4:e13006

18. Livak KJ, Schmittgen TD. Analysis of relative gene expression data using real-time quantitative $P C R$ and the $2-\Delta \Delta C T$ method. Methods. 2001; 25(4):402-8

19. Dubois V, Laurent M, Boonen S, Vanderschueren D, Claessens F. Androgens and skeletal muscle: cellular and molecular action mechanisms underlying the anabolic actions. Cell Mol Life Sci. 2012;69:1651-67.

20. Gapstur SM, Gann PH, Kopp P, Colangelo L, Longcope C, Liu K. Serum androgen concentrations in young men: a longitudinal analysis of associations with age, obesity, and race. The CARDIA male hormone study. Cancer Epidemiol Biomark Prev. 2002;11:1041-7.

21. Chen JL, Zhao GP, Zheng MQ, Wen J, Yang N. Estimation of genetic parameters for contents of intramuscular fat and Inosine-5'monophosphate and carcass traits in Chinese Beijing-you chickens. Poultry Sci. 2008;87:1098-104

22. Cui X, Liu R, Cui H, Zhao G, Zheng M, Li Q, Liu J, Liu Z, Wen J. Effects of caponization and ovariectomy on objective indices related to meat quality in chickens. Poult Sci. 2016;96:770-7.

23. Sinanoglou VJ, Mantis F, Miniadismeimaroglou S, Symeon GK, Bizelis I. Effects of caponisation on lipid and fatty acid composition of intramuscular and abdominal fat of medium-growth broilers. Brit Poultry Sci. 2011;52(3):310.

24. Kwiecień M, Kasperek K, Grela E, Jeżewska-Witkowska G. Effect of caponization on the production performance, slaughter yield and fatty acid profile of muscles of Greenleg partridge cocks. J Food Sci Technol. 2015;52: 7227-35.

25. Chen K, Chi W, Chu C, Chen R, Chiou P. Effect of caponization and testosterone implantation on hepatic lipids and lipogenic enzymes in male chickens. Poult Sci. 2007:86:1754-9.

26. Benítez R, Núñez Y, Fernández A, Isabel B, Rodríguez C, Daza A, López-Bote C, Silió L, Óvilo C. Adipose tissue transcriptional response of lipid metabolism genes in growing Iberian pigs fed oleic acid v. Carbohydrate enriched diets. Anima. 2016;10:939-46.

27. Regassa A, Kim WK. Transcriptome analysis of hen preadipocytes treated with an adipogenic cocktail (DMIOA) with or without 20(S)-hydroxyl -cholesterol. BMC Genomics. 2015;6:91.
28. Vergani L, Fanin M, Martinuzzi A, Galassi A, Appi A, Carrozzo R, Rosa M, Angelini C. Liver fatty acid-binding protein in two cases of human lipid storage. Mol Cell Biochem. 1990;98:225-30.

29. Xue W, Wang W, Jin B, Zhang X, Xu X. Association of the ADRB3, FABP3, LIPE, and LPL gene polymorphisms with pig intramuscular fat content and fatty acid composition. Czech J Anim Sci. 2015;60:60-6.

30. Wang G, Williams CA, McConn BR, Cline MA, Gilbert ER. A high fat diet enhances the sensitivity of chick adipose tissue to the effects of centrally injected neuropeptide $Y$ on gene expression of adipogenesis-associated factors. Comp Biochem Physiol A Mol Integr Physiol. 2017;211:49-55.

31. Hu G, Wang SZ, Wang ZP, Li YM, Li H. Genetic epistasis analysis of 10 peroxisome proliferator-activated receptor $\gamma$-correlated genes in broiler lines divergently selected for abdominal fat content. Poult Sci. 2010;89:2341-50.

32. Shi H, Wang Q, Wang Y, Leng L, Zhang Q, Shang Z, Li H. Adipocyte fatty acid-binding protein: an important gene related to lipid metabolism in chickenadipocytes. Comp Biochem Physiol B Biochem Mol Biol. 2010;157:357-63.

33. Douaire M, Le Fur N, el Khadir-Mounier C, Langlois P, Flamant F, Mallard J. Identifying genes involved in the variability of genetic fatness in the growing chicken. Poult Sci. 1992;71:1911-20.

34. Zhang JJ, Hao JJ, Zhang YR, Wang YL, Li MY, Miao HL, Zou XJ, Liang B. Zinc mediates the SREBP-SCD axis to regulate lipid metabolism in Caenorhabditis elegans. J Lipid Res. 2017;58:1845-54.

35. Boschetti E, Bordoni A, Meluzzi A, Castellini C, Dal Bosco A, Sirri F. Fatty acid composition of chicken breast meat is dependent on genotype-related variation of FADS1 and FADS2 gene expression and desaturating activity. Animal. 2016;10:700-8.

36. Guo X, Nan H, Shi D, Zhou J, Wan Y, Zhou B, Geng Z, Chen X, Jiang R. Effects of caponization on growth, carcass, and meat characteristics and the mRNA expression of genes related to lipid metabolism in roosters of a Chinese indigenous breed. Czech J of Anim Sci. 2015;60:327-33.

37. Cui HX, Liu RR, Zhao GP, Zheng MQ, Chen JL, Wen J. Identification of differentially expressed genes and pathways for intramuscular fat deposition in pectoralis major tissues of fast-and slow-growing chickens. BMC Genomics. 2012;13:1.

Ready to submit your research? Choose BMC and benefit from

- fast, convenient online submission

- thorough peer review by experienced researchers in your field

- rapid publication on acceptance

- support for research data, including large and complex data types

- gold Open Access which fosters wider collaboration and increased citations

- maximum visibility for your research: over $100 \mathrm{M}$ website views per year

At BMC, research is always in progress.

Learn more biomedcentral.com/submissions 